\title{
Tobacco Chemistry
}

\section{8**: Chemical and Cillotoxic Studies of Smoke from Heat-Treated Tobacco*}

by

C. R. Enzell, Chemical Research Department, Swedish Tobacco Co., Stodkholm, Sweden,

E. Bergstedt, Institute of Analytical Chemistry, University of Stockholm, Stodkolm, Sweden,

T. Dalhamn, Institute of Hygiene, University of Uppsala, Uppsala, Sweden,

W. H. Johnson, Department of Biological and Agricultural Engineering, North Carolina State

University, Raleigh, N.C., U.S.A.

\section{INTRODUCTION}

Heat treatment of yellowed tobacco during curing, recently discussed by one of us ( $x$ ), constitutes a means of altering the colour and certain chemical characteristics of tobacco. The method which involves rapid increase of the temperature of high moisture leaf to about $80^{\circ} \mathrm{C}$ for a limited time, produces extensive protoplasmic disorganization for effective initiation of oxidative browning (o-diphenol oxidation). The subsequent reaction and color change occurs rapidly and, under optimal conditions, can go to completion within 20 to zo minutes. The degree of oxidative browning can, essentially independent of other parameters, be regulated by variation of leaf temperature and exposure time.

In view of the fact that observed color changes are related to certain dhemical changes in the leaf $(1-3)$ in particular to significant reduction in polyphenol and nicotine contents, it was of obvious interest to examine the chemical composition and ciliotoxic effects of smoke derived exclusively from such tobacco. The present study was therefore undertaken and deals with differences observed between tobaccos heat-treated in the laboratory or in the curing barn and corresponding conventionally cured material as regards particulate matter, nicotine, phenol and ciliotoxic activity of the smoke. Moreover, a detailed gas dhromatographic and mass spectrometric examination of the gas phase of fresh smoke from these differently treated tobaccos has been performed.

\section{MATERIALS AND METHODS}

\section{Tobacco and Cigarettes}

Tobacco (Nicotiana tabacum L., cv. NC 2326) was grown for this study at the Tobacco Research Station, Oxford, N.C., during 1968. Normal cultural practices were followed. Tobacco was harvested at maturity with four successive primings at approximately 2-week intervals over a period of six weeks.

\footnotetext{
* Received for publication: 23rd Agril, 1971.

* Part 7; A. Aasen, B. Kimland, and C. R. Enzell, Acta Chem. Scand, in press.
}

At each harvest the tobacco was randomized and submitted to three distinct curing treatments as follows:

1. Control: Tobacco was yellowed and dried by the conventional flue-curing schedule. Curing conditions were accomplished in compartmental curing facilities as described by Humphries and Johnson (4). During the yellowing phase, air was circulated at approximately $35^{\circ} \mathrm{C}$ and $85-90 \%$ r.h. for about 36-72 hours. Drying was accomplished by progressively increasing air temperature to about $75^{\circ} \mathrm{C}$ over a $30-\mathrm{hr}$ period, with concurrent reduction of humidity, then maintaining this temperature until midribs were dry. The total curing period was approximately four to five days.

2. Heat treatment in laboratory (HTL): Yellowing and drying conditions for this treatment were identical to the control. However at the end of yellowing, tobacco was removed from the curing units and brought to high moisture by immersion of petioles in water for several hours. Leaves were then heat-treated by passing them in a vertical plane between two banks of infrared lamps. Within 20 seconds, the leaf temperatures was elevated to $80^{\circ} \mathrm{C}$, thus initiating oxidative browning. The reaction was then allowed to proceed to completion at room temperature for at least 30 minutes, and the tobacco was replaced into the curing units and dried in the same way as the control.

3. Heat treatment in curing barn (HTB): Again yellowing and drying conditions were identical with the control; however a heat treatment was imposed on the yellowed leaf directly in the barn. The barn was closed tightly and air-recirculated. Then the air temperature was rapidly elevated to $80^{\circ} \mathrm{C}$ within 30-60 min. to effect oxidative browning. Air humidity within the barn during this period was near saturation. The dampers were then opened, temperatures were lowered within minutes to $35^{\circ} \mathrm{C}$ and drying allowed to proceed according to the schedule for the control.

Following drying, all samples were conditioned for handling without breakage and were stored for subsequent processing and evaluation.

Prior to cigarette manufacture, tobacco from various leaf positions (four harvests) within each treatment 
was composited and uniformly blended. Cigarettes $(70 \times 8 \mathrm{~mm})$ were prepared by a cooperating tobacco manufacturer using 32 cuts/inch and a regular type of cigarette paper. In manufacturing the cigarettes, the machine was set to achieve cigarettes from the three tobacco lots having the same draw resistance.

\section{Smoking Procedure and Chemical Examination of the Smoke}

On arriving in Sweden the cigarettes were moistureequilibrated at 65 per cent relative humidity and $25^{\circ} \mathrm{C}$. The cigarettes prepared from the tobacco heattreated in laboratory or heat-treated in curing barn were selected to within $\pm 20 \mathrm{mg}$ of an average weight of $790 \mathrm{mg}$ and to within $\pm 20 \mathrm{mg}$ of an average weight of $885 \mathrm{mg}$ respectively. The corresponding figures for cigarettes made from conventionally cured material were $\pm 20 \mathrm{mg}$ and $873 \mathrm{mg}$.

All types of cigarettes were smoked mechanically on a Phipps \& Bird machine (5) using Cambridge filters for trapping the particulate matter (puff volume $35 \mathrm{ml}$, puff duration $2 \mathrm{sec}$, puff frequency I puff/min., butt length $23 \mathrm{~mm}$ ). The determination of the amount of total particulate matter and its water content were performed according to the CORESTA standard method no. 1o (6). The amount of nicotine was determined by the CORESTA standard method no. 12 (7). The determination of "phenol" in the particulate matter, which accounts for 97 percent of total smoke "phenol" value according to earlier investigations, was accomplished using a method of Williamson (8) modified by Carlson (9), which is based on spectroscopic determination $(480 \mathrm{~nm})$ after treatment of the separated acidic material with diazotized p-nitroaniline. The results of these determinations are given in Table 4.

\section{Ciliotoxicity of the Smoke}

The ciliotoxicity of the smoke derived from the three types of cigarettes was examined by passing the fresh smoke over rabbit trachea in vitro and observing the number off puffs required to complete ciliostasis using conditions discussed in detail elsewhere (10). In the present investigation five determinations using five pieces of trachea were performed with the cigarettes prepared from the two differently heat-treated materials

Table 1. Number of cigarettes and puffe required to complete cillostasis of rabblt trachea in vitro using cigarettes of tobacco heat-treated in laboratory (HTL) or in barn (HTB) and of conventionally cured tobacco (Control).

\begin{tabular}{|c|c|c|c|c|c|c|}
\hline \multicolumn{3}{|c|}{ HTL } & \multicolumn{2}{|c|}{ HTB } & \multicolumn{2}{|c|}{ Control } \\
\hline & $\begin{array}{c}\text { Number } \\
\text { of } \\
\text { cigarettes }\end{array}$ & $\begin{array}{c}\text { Number } \\
\text { of } \\
\text { puffs }\end{array}$ & $\begin{array}{c}\text { Number } \\
\text { of } \\
\text { cigarettes }\end{array}$ & $\begin{array}{c}\text { Number } \\
\text { of } \\
\text { puffs }\end{array}$ & $\begin{array}{c}\text { Number } \\
\text { of } \\
\text { cigarettes }\end{array}$ & $\begin{array}{c}\begin{array}{c}\text { Number } \\
\text { of } \\
\text { puffs }\end{array} \\
\end{array}$ \\
\hline & 8 & 60 & 7 & 60 & 12 & 97 \\
\hline & 12 & 96 & 8 & 68 & 11 & 92 \\
\hline & 9 & 67 & 18 & 141 & 17 & 144 \\
\hline & 8 & 63 & 11 & 89 & 12 & 98 \\
\hline & 9 & 73 & 10 & 84 & 10 & 86 \\
\hline$\overline{\mathbf{M}}$ & 9.2 & 72 & 10.8 & 88 & 12.4 & 103 \\
\hline
\end{tabular}

and from the conventionally cured tobacco. The results of these studies are detailed in Table 1 .

\section{Gas Chromatographic and Mass Spectrometric Examination of the Gas Phase}

The smoking was accomplished with the aid of a device described in a previous paper in this series (11). The cigarettes were smoked in puffs of $35 \mathrm{ml}$ during two seconds and with one minute intervals. In the present investigation all $\mathrm{gc}$ and $\mathrm{gc}-\mathrm{ms}$ analyses were performed on the third puff.

The gas chromatographic separation was carried out on a previously described homemade instrument, which has a very small dead volume in the inlet-split-tocolumn and column-to-detector connections (12). The instrument has been modified in such a way that a linear temperature programming between $-70^{\circ}$ and $130^{\circ} \mathrm{C}$ can be achieved. A glass capillary column (110 $\mathrm{m}, \mathrm{i}$. d. $0.2 \mathrm{~mm}$ ) coated with SF 96 and having and efficiency of above 500,000 theoretical plates (measured for toluene at room temperature) was used, both when a flame ionisation detector and an LKB 9000 mass spectrometer were employed for detection.

The analyses were performed by injecting $10 \mathrm{ml}$ of gas phase using a split ratio of $I: 40$ and increasing the temperature of the column oven from $-70^{\circ}$ to $130^{\circ} \mathrm{C}$ linearly at $2 \% \mathrm{~min}$. The injection block was kept at $100^{\circ} \mathrm{C}$ and the detector at $150^{\circ} \mathrm{C}$. Nitrogen (inlet pressure $1.9 \mathrm{~kg} / \mathrm{cm}^{2}$, flow rate $0.30 \mathrm{ml} / \mathrm{min}$. at $\left.20^{\circ} \mathrm{C}\right)$ was used as carrier gas when the flame ionisation detector was utilised and the results obtained are given in Figure 1 .

When the column was attached to the separator of the mass spectrometer, which was kept at $220^{\circ} \mathrm{C}$, the coupling previously described by Novotny (13) was used. Nitrogen was substituted for helium as carier gas and the inlet pressure increased to $3 \mathrm{~kg} / \mathrm{cm}^{2}$. The mass spectra were recorded at $70 \mathrm{eV}$ with the aid of a data acquisition system developed by Bergstedt et al. (14), which was coupled on line to the mass spectrometer. A small computer with computing routines for background subtraction and normalization was employed to facilitate and improve the accuracy of the analysis of the recorded spectra. The compounds identified or representing the best fit are given in Table 5, which also details the retention times and molecular weights of the majority of the compounds encountered.

\section{RESULTS AND DISCUSSION}

The process of heat treatment of tobacco, recently discussed by Johnson (1), appears potentially important from the standpoint of controlled modification of polyphenols and nicotine. In previous work (3) on laboratory heat treatment of yellowed, turgid tobacco under infrared irradiation, polyphenol contents were reduced by up to $85 \%$. Chemical analyses of samples from this study were conducted for polyphenols, nico- 
Table 2. Effect of heat treatment in laboratory (HTL) and in barn (HTB) during curing on polyphenol and nicotine contents of tobacco.

\begin{tabular}{|c|c|c|c|c|c|c|}
\hline $\begin{array}{c}\text { Leaf } \\
\text { constituent }\end{array}$ & Treatment & 1 & 2 & 3 & 4 & Means \\
\hline \multirow[t]{2}{*}{$\begin{array}{l}\text { Total } \\
\text { polyphenols } \\
(\mathrm{mg} / \mathrm{g})^{*}\end{array}$} & $\begin{array}{l}\text { Control } \\
\text { HTL } \\
\text { HTB }\end{array}$ & $\begin{array}{l}40.3 \\
14.7 \\
28.6 \\
27.87\end{array}$ & $\begin{array}{l}51.9 \\
12.5 \\
19.4 \\
27.93\end{array}$ & $\begin{array}{c}48.8 \\
8.1 \\
20.7 \\
25.87\end{array}$ & $\begin{array}{c}49.1 \\
8.7 \\
19.8 \\
25.87\end{array}$ & $\begin{array}{l}47.5 \\
11.1 \\
22.1\end{array}$ \\
\hline & Treatment m & $.05)=$ & & & & \\
\hline \multirow[t]{2}{*}{$\begin{array}{l}\text { Nicotine } \\
\text { (per cent) }\end{array}$} & $\begin{array}{l}\text { Control } \\
\text { HTL } \\
\text { HTB }\end{array}$ & $\begin{array}{l}2.11 \\
1.94 \\
2.16 \\
2.07\end{array}$ & $\begin{array}{l}2.75 \\
2.65 \\
2.16 \\
2.52\end{array}$ & $\begin{array}{l}3.82 \\
3.61 \\
3.18 \\
3.54\end{array}$ & $\begin{array}{l}4.98 \\
3.96 \\
4.01 \\
4.32\end{array}$ & $\begin{array}{l}3.42 \\
3.04 \\
2.88\end{array}$ \\
\hline & Treatment $m$ & .05) $=$ & & & & \\
\hline
\end{tabular}

- Expressed as equivalent $\mathrm{mg}$ of chlorogenic acid per gram tobacco.

tine, total nitrogen and reducing sugars. The latter two constituents were not significantly affected; however polyphenols and nicotine showed significant changes as shown in Table 2.

These results showed that laboratory heat treatment under infrared irradiation reduced polyphenols by $76 \%$ and nicotine by $11 \%$; whereas barn heat treatment gave reductions of $53 \%$ and $16 \%$, respectively. Separate analyses on composite samples gave polyphenol reductions of $82 \%$ and $60 \%$ and nicotine reduction of $24 \%$ und $24 \%$ for the two respective heat treatments.

Before discussing the chemical and biological results, certain properties achieved by heat treatment or in cigarette manufacture should be noted. A prominent physical characteristic of the heat-treated tobaccos is the uniform tan to light brown pigmentation achieved during oxidative browning. This characteristic is apparently associated with polymerization of polyphenols with amino acids, alkaloids, etc. in the formation of high molecular weight brown pigments. The process does not appear to adversely affect textural character, in fact, the cured treated tobaccos exhibit unusually acceptable characteristics of graininess, body, and elasticity.

Smoke panel evaluations of the processed samples, made in cooperation with seven tobacco companies, have provided ratings for mildness and preference and these are summarized in Table 3 .

Table 3. Smoke panel ratings for clgarettes of tobaccos heat-treated in laboratory (HTL) or in barn (HTB) and of conventlonally cured tobacco (Control). Numbers represent total ratings recelved from 7 companles.

\begin{tabular}{l|l|c|c}
\hline \multirow{2}{*}{$\begin{array}{l}\text { camples } \\
\text { compared }\end{array}$} & \multirow{2}{*}{ Treatment } & \multicolumn{2}{|c}{ Ratings } \\
& & Milder & Prefer \\
\hline Control vs. HTL & Control & 50 & 53 \\
& HTL & 50 & 46 \\
Control vs. HTB & Control & 31 & 36 \\
& HTB & 72 & 65 \\
HTB vs. HTL & HTL & 31 & 29 \\
& HTB & 58 & 61 \\
\hline
\end{tabular}

The results show little difference between the laboratory heat-treated tobacco in comparison with the control; however, the barn heat-treated tobacco gave indication of greater mildness and preference in comparison with the control or laboratory heat-treated tobacco. The apparent favorable effect may be related to the longer time of heat treatment in the barn under high moisture and temperature conditions where more extensive biochemical changes could occur.

The results of the determinations of total particulate matter (TPM), dry condensate (TPM minus water), nicotine, "phenols", and ciliotoxic activity of the smoke derived from the three types of tobacco are summarized in Table 4, which also gives the average weight per cigarette and the average number of puffs per cigarette.

It follows from these figures and those given in Table I that only fairly minor differences are encountered. However, there are five differences which are noteworthy. Thus the reductions in the nicotine, TMP, dry condensate, and phenol content of the smoke from the tobacco heat-treated in the barn in relation to those of the control are significant even when these figures are compared on the basis of an equal amount of tobacco or equal number of puffs. The reduction

Table 4. Dlfferences between clgarettes of tobacco heattreated in laboratory (HTL) or In barn (HTB) and of conventionally cured tobacco (Control).

\begin{tabular}{|c|c|c|c|}
\hline & Control & HTL & HTB \\
\hline Average weight, $\mathrm{mg} /$ cigarette & 873 & 790 & 885 \\
\hline $\begin{array}{l}\text { puffs/cigarette } \\
\text { Total particulate matter (TPM), }\end{array}$ & 8.4 & 7.5 & 8.1 \\
\hline $\begin{array}{l}\text { mg/cigarette } \\
\text { Dry condensate }\left(\mathrm{TPM}-\mathrm{H}_{2} \mathrm{O}\right) \text {, }\end{array}$ & 45.5 & 44.0 & 41.7 \\
\hline $\mathrm{mg} /$ cigarette & 40 & 38 & 37 \\
\hline Nicotine, mg/cigarette & 4.9 & 3.9 & 3.8 \\
\hline $\begin{array}{l}\text { "Phenol", } \mu \mathrm{g} / \text { cigarette } \\
\text { Ciliostasis subsequent to }\end{array}$ & 322 & 299 & 286 \\
\hline number of cigarettes & 12.4 & 9.2 & 10.8 \\
\hline number of puffs & 103 & 72 & 88 \\
\hline
\end{tabular}


of the amount of nicotine in the smoke is of the same order ( $16 \%$, based on equal weights of tobacco) as that observed for the tobacco and the reason for this and for the other reductions mentioned is apparently related to the changes in the tobacco noted above. A further interesting difference, significant at a $95 \%$ confidence level, is the reduction in ciliotoxicity of the smoke from the tobacco heat-treated in the laboratory in relation to the control. The reasons for this and for the lack of corresponding reduction for the barn heat-treated tobacco are less obvious but may be related to the possibility that the dhemical changes occuring in the tobacco on rapid heating under infrared irradiation can take a somewhat different course than in the case of the slower heat treatment in the barn.

In order to establish if the gas phase of the smoke from heat-treated (laboratory and curing barn) and conventionally cured tobaccos differ, analyses were performed with the aid of a high resolution gas dhromatographic system described in a previous paper in this series (12). The results of these studies, whidh also involved gas chromatography in combination with mass spectrometry, are given in Figure $I$ and Table 5.

All analyses were performed on fresh smoke to suppress secondary reactions. The gas phase of the third puff was analysed and, as detailed in the experimental part, to $\mathrm{ml}$ of this material were injected directly onto the cooled column without prior condensation or concentration. The reproducible conditions required to allow meaningful comparison between the gas chromatograms of the gas phases from different types of tobaccos were achieved after redesigning the previously described instrument in such a way that the temperature could be increased linearly from $-70^{\circ}$ to $130^{\circ} \mathrm{C}$. The limiting factor of reproduceability, as demonstrated by repeated analysis of the same tobacco, was now the inhomogenity of the material analysed. These and similar experiments also revealed certain intensity variations, notably of the peaks encountered at the retention-time intervals 17-19 min. (peaks 8-10), 28-34 min. (peaks 28-21), and 40-43 min. (peaks 40-43), and moreover that these effects were randomly distributed and could not be associated with any special type of tobacco. All examinations were performed on a 110-meter glass capillary column coated with SF 96 . This stationary phase was selected because it retains the separation efficiency even at very low temperatures $\left(-70^{\circ} \mathrm{C}\right)$ and is well suited for the separation of hydrocarbons and compounds of similar polarity, which, according to the pioneering work of Grob $(15,16)$, represent the most prominent group of the gas phase constituents. However, it has the disadvantage that it is less satisfactory for polar compounds.

When taking these factors into account it may be concluded that there are no significant differences between the chromatograms of the gas phase from the two types of heat-treated and the conventionally cured tobaccos, cf. Figure 1 .

When coupled to the mass spectrometer, the high resolution of the gas dhromatographic system was retained after altering, the Becker-Ryhage separator as described by Novotny (13). While the sensitivity of the flame ionisaion defector was adequate under the conditions used, the concentration of several gas phase components were too low to give satisfactory spectra. A further limitation was the complexity of the gas phase, which restricted the recording of background spectra required to compensate for all bleeding and overlapping effects encountered. The analysis of the mass spectra, recorded with the aid of a data acquisition system, was however simplified and improved by the use of a small computer with computing routines for background subtraction and normalization.

The mass spectrometric results, summarized in Table 5, indicate that the vast majority of the compounds in the gas phase from the tobacco heat-treated in laboratory are identical to those of corresponding gas chromatographic properties present in the gas phases from the tobacco heat-treated in curing barn and from the conventionally cured material. Although minor differences are encountered (cf. Table 5), these evidently lack significance. It should be noted that the structural assigments made in Table 5 are at different levels of confidence on account of the inherent limitations of mass spectrometry and that many of the assignments only constitute the best fit of the available reference data $(17-20)$. To indicate when the presence of a compound is taken as established the name is given in bold type.

In a previous paper in this series (11), a detailed gas chromatographic and mass spectrometric examination of the gas phases of fresh smoke from cigarettes made from freeze-dried tobacco was reported. Comparison of the present results and those obtained for the freeze-dried tobacco reveals no significant difference in the examined gas phases. On the other hand, there are obvious differences from the results earlier reported by Grob (16), noticeably in the respect that fewer oxygenated compounds were encountered in the present study. Although it was assumed in the paper dealing with freeze-dried tobacco $(x)$ that these differences could be related partly to the fact that the procedure used by Grob (16), involving condensation of the gas phase of cigarette smoke and injection of the condensate as an ether solution, might lead to an increase of oxygenated substituents, it now seems clear from results obtained by Grob (23) that no artefacts arise in the procedure used by him, and hence that the observed differences may rather be a result mainly of different sampling and dhromatographic conditions.

\section{SUMMARY}

Heat-treated and corresponding conventionally cured tobacco have been subjected to comparative studies. The heat-treating process has been carried out under laboratory and curing barn conditions. Analyses of the three different tobaccos show that the heat treatment leads to a considerable reduction of the polyphenols and a less pronounced reduction of nicotine. Determinations of the amount of total par- 


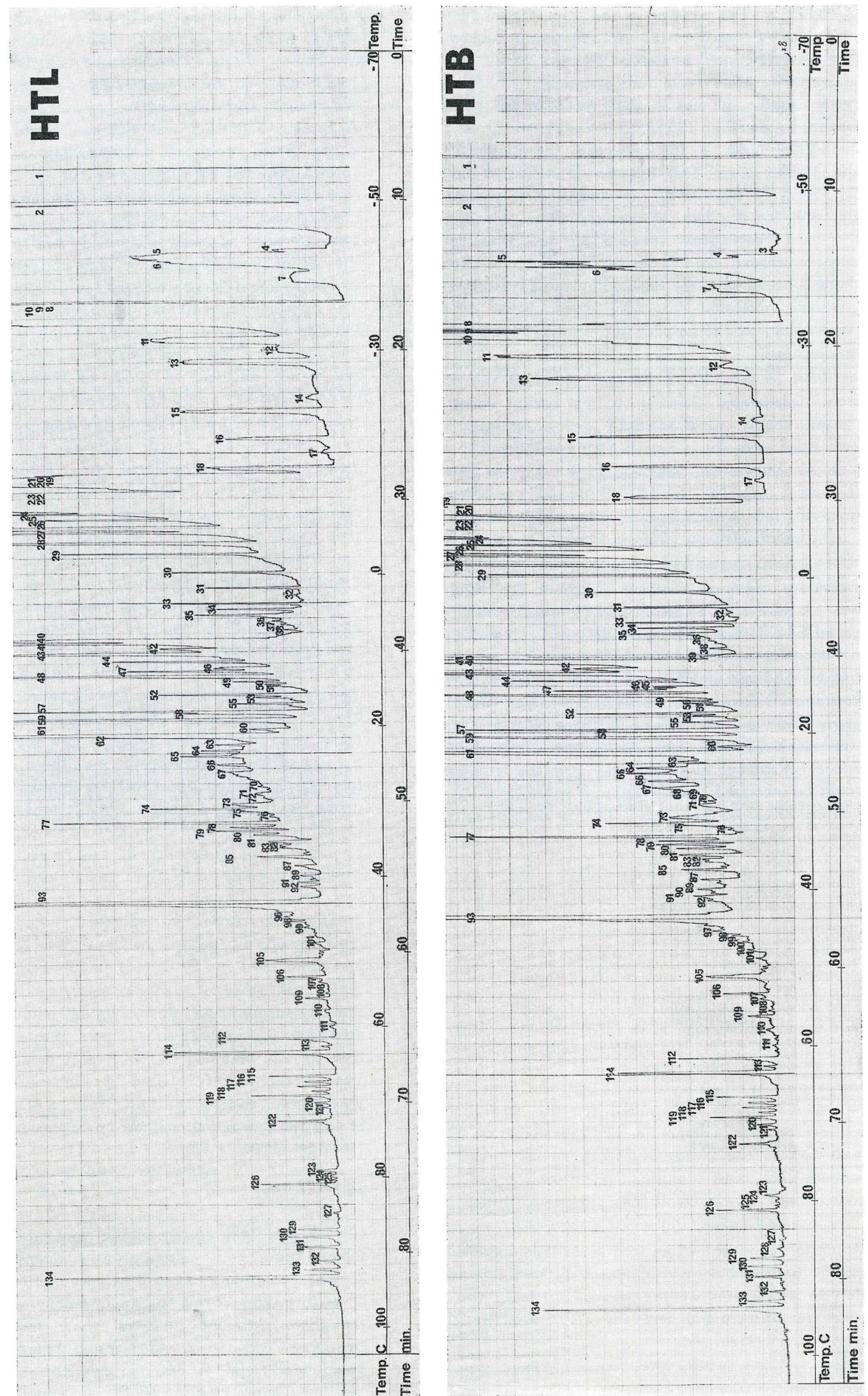




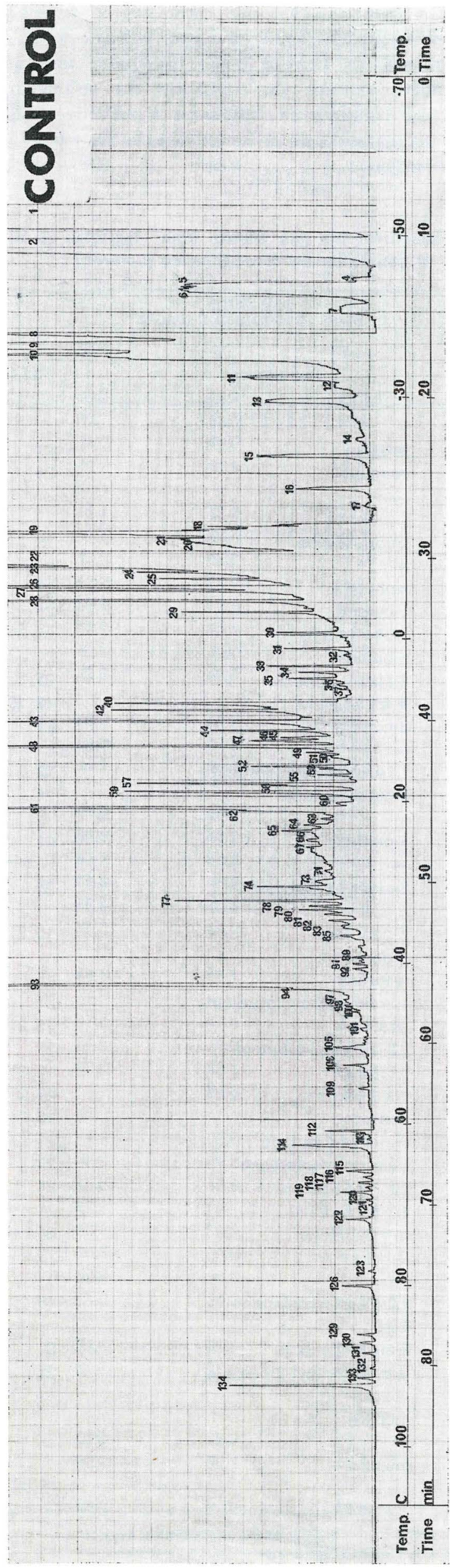

ticulate matter, dry condensate, nicotine, and "phenol" in the smoke from cigarettes manufactured from the three types of tobaccos show that the heat treatment in the barn gives rise to a small but relevant lowering of these values. Examination of the ciliotoxic effect of the smokes on rabbit trachea in vitro reveals that there is a significant, although moderate, difference between the tobacco heat-treated in the laboratory and the control as regards the number of puffs required to achieve complete ciliostasis.

A detailed gas chromatographic-mass spectrometric study using a high resolution glass capillary column and computerised data-acquisition demonstrates the absence of significant differences in the gas phases of the smoke derived from the differently treated tobaccos.

\section{ZUSAMMENFASSUNG}

Die Autoren vergleichen Tabake, die einer Schnelltrocknung unterworfen wurden, mit entsprechenden herkömmlich getrockneten Tabaken. Die Schnelltrocknung wurde sowohl im Laboratorium als auch im Trockenschuppen durchgeführt. Die Schnelltrocknung führt zu einer beträchtlichen Verminderung des Gehaltes an Polyphenolen und zu einer weniger ausgeprägten Verminderung des Nikotingehaltes. Aus den Bestimmungen des Gesamtkondensates, des Trockenkondensates, des Nikotins und der "Phenole" im Rauch von Cigaretten, die aus den drei unterschiedlich behandelten Tabaken gefertigt worden waren, ist ersichtlich, daß die Schnelltrocknung im Trockenschuppen $z \mathbf{u}$ einer geringen, aber bedeutsamen Verminderung dieser Werte führt. Die ziliotoxische Wirkung des Rauches der drei Tabake wurde in vitro an der Trachea von Kaninchen geprüft. Gemessen an der Zahl der Züge bis zur völligen Ziliostase ergab sich ein geringer, aber signifikanter Unterschied zwischen dem Tabak, der im Laboratorium einer Schnelltrocknung unterworfen wurde, und den entsprechenden Kontrolltabaken.

Durch Computer ausgewertete Untersuchungen mit einer Kombination von Gaschromatographie und Massenspektrometrie und dem Einsatz einer hochauflösenden Glaskapillarsäule ergaben Analysenwerte, nach denen sich die Gasphasen des Rauches der drei verschiedenartig getrockneten Tabake nicht signifikant voneinander unterscheiden.

\section{RESUME}

On a fait des études comparatives de tabac traité à la chaleur et correspondant à ceci, de tabac traité conventionnellement. Le procédé de traitement à la chaleur a été effectué dans des conditions de laboratoire et de séchage industriel. Les analyses des trois différents tabacs démontrent que le traitement à la chaleur mène à une réduction considérable des polyphénols et à une réduction moins prononcée de la nicotine. Les déterminations des quantités des matières totales particulaires, des condensats secs, de la nicotine, et du "phénol» dans la fumée provenant de cigarettes fabriquées avec les trois types de tabac, démontrent que le traitement à la chaleur dans le séchage industriel provoque une 
diminution minime mais significative de ces valeurs. L'examen' in vitro de l'effet ciliotoxique des fumées sur les trachées des lapins révèle qu'il $y$ a une différence significative, quoique modérée, entre le tabac traité à la chaleur au laboratoire et le contrôle en ce qui concerne le nombre de bouffées nécessaires pour achever la ciliostase complète.
Une étude détaillée par chromatographie en phase gazeuse-spectrographie de masse, utilisant des colonnes capillaires en verre à haute résolution, ainsi que de données acquises par traitement sur ordinateur, démontre l'absence de différences significatives dans les phases gazeuses de la fumée dérivée des tabacs traités différemment.

Table 5. Gas chromatographle and mass spectrometric results oblained for the gas phases from clgarettes of tobacco heat-treated in laboratory (HTL) or In barn (HTB) and of conventionally cured tobacco (Control).

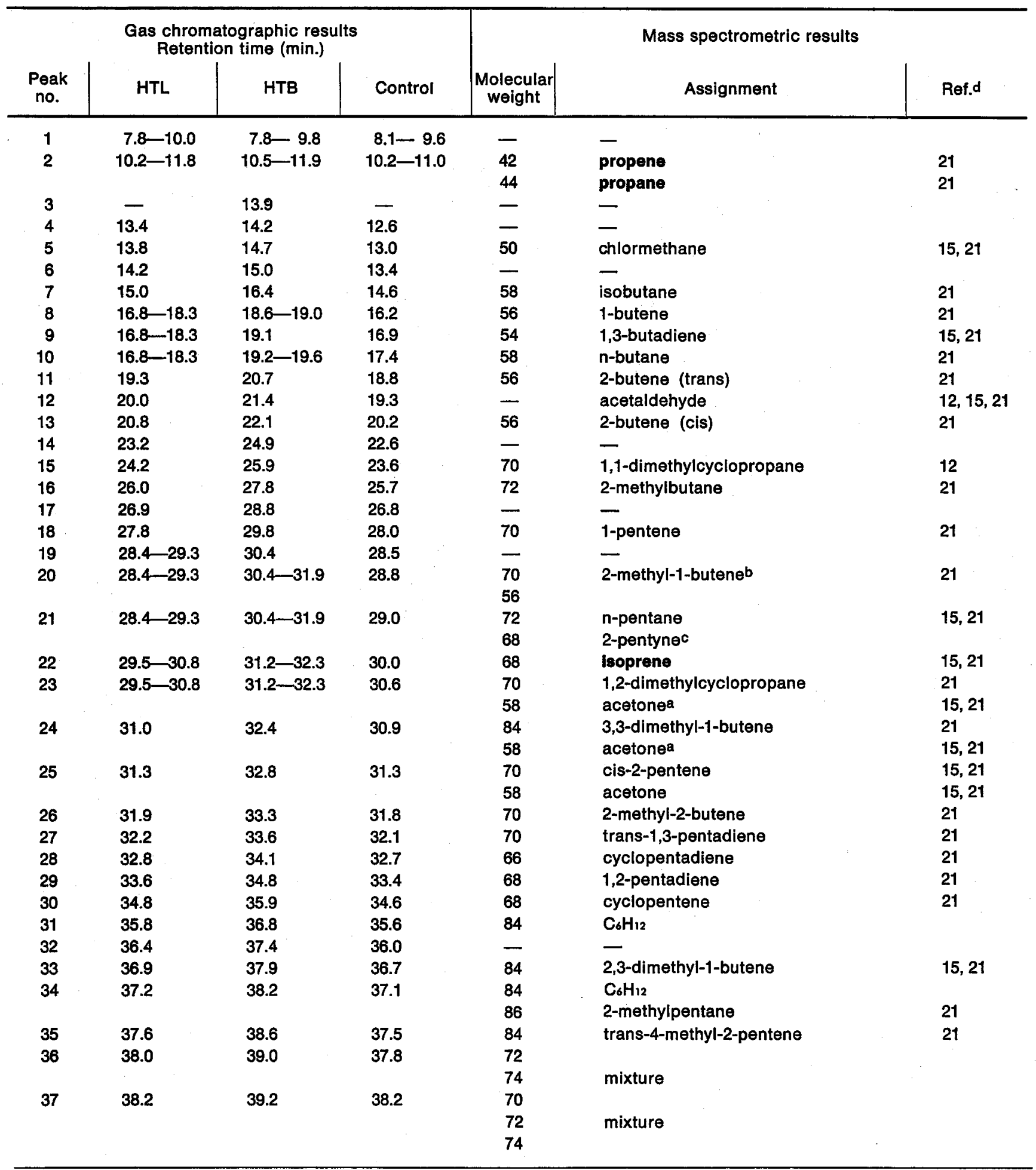




\begin{tabular}{|c|c|c|c|c|c|c|}
\hline \multirow[b]{2}{*}{$\begin{array}{c}\text { Peak } \\
\text { no. }\end{array}$} & \multicolumn{3}{|c|}{$\begin{array}{l}\text { Gas chromatographic results } \\
\text { Retention time (min.) }\end{array}$} & \multirow[b]{2}{*}{$\begin{array}{c}\text { Molecular } \\
\text { weight }\end{array}$} & \multicolumn{2}{|l|}{ Mass spectrometric results } \\
\hline & HTL & HTB & Control & & Assignment & Ref.d \\
\hline \multirow[t]{3}{*}{38} & 38.6 & 39.6 & 一 & 70 & & \\
\hline & & & & 72 & mixture & \\
\hline & & & & 74 & & \\
\hline 39 & - & - & - & 86 & - & \\
\hline \multirow[t]{2}{*}{40} & 39.4 & $40.2-40.4$ & 39.0 & 84 & methyl-cyclopentane & 21 \\
\hline & & & & 86 & methyl-isopropanone & 15,21 \\
\hline \multirow[t]{2}{*}{41} & 39.6 & $40.2-40.4$ & 39.3 & 84 & 1-hexene & 21 \\
\hline & & & & 86 & $\mathrm{C}_{6} \mathrm{H}_{14}$ & \\
\hline \multirow[t]{2}{*}{42} & 39.9 & 40.7 & 39.4 & 70 & & \\
\hline & & & & 86 & - & \\
\hline 43 & 40.2 & 41.1 & 40.2 & 82 & 2-methylfuran & 15,21 \\
\hline 44 & 40.7 & 41.5 & 40.6 & 86 & n-hexane & 15,21 \\
\hline 45 & 41.0 & 41.8 & 41.1 & - & - & \\
\hline \multirow[t]{2}{*}{46} & 41.2 & 42.0 & 41.2 & 72 & 2-butanone & 15,21 \\
\hline & & & & 82 & & \\
\hline 47 & 41.4 & 42.2 & 41.3 & 82 & 1-hexyne & \\
\hline 48 & 41.7 & 42.4 & 41.7 & 84 & 2-methyl-2-pentene & 21 \\
\hline 49 & 42.0 & 42.8 & 42.0 & 82 & 2-methyl-1,3-pentadiene & \\
\hline 50 & 42.2 & 43.0 & 42.2 & 82 & 2-hexyne & \\
\hline 51 & 42.3 & 43.1 & 42.3 & - & - & \\
\hline 52 & 42.9 & 43.6 & 42.9 & 84 & 3-hexene & \\
\hline 53 & 43.1 & 43.8 & 43.0 & 82 & $\mathrm{C}_{6} \mathrm{H}_{10}$ & \\
\hline \multirow[t]{2}{*}{54} & 43.2 & 44.0 & - & 82 & $\mathrm{C}_{6} \mathrm{H}_{10}$ & \\
\hline & & & & 84 & $\mathrm{C}_{6} \mathrm{H}_{12}$ & \\
\hline 55 & 43.5 & 44.2 & 43.4 & 78 & butadienylacetylene ${ }^{a}$ & \\
\hline 56 & 43.6 & 44.3 & 43.6 . & - & - & \\
\hline \multirow[t]{2}{*}{57} & 44.1 & 44.7 & 44.0 & 78 & $\mathrm{C}_{6} \mathrm{H}_{6}$ & \\
\hline & & & & 80 & 1,3-cyclohexadiene & \\
\hline 58 & 44.2 & 44.8 & 44.0 & 82 & 3-hexyne & \\
\hline 59 & 44.6 & 45.2 & 44.4 & 80 & - & \\
\hline 60 & 45.2 & 45.8 & 45.2 & 82 & 2-methyl-1,3-pentadiene & \\
\hline 61 & 45.6 & 46.2 & 45.5 & 78 & benzene & 15,21 \\
\hline 62 & 45.8 & 46.4 & 45.6 & 82 & $\mathrm{C}_{6} \mathrm{H}_{10}$ & \\
\hline \multirow[t]{2}{*}{63} & 46.2 & 46.8 & 46.1 & 82 & mixture & \\
\hline & & & & 84 & & \\
\hline \multirow[t]{2}{*}{64} & 46.6 & 47.1 & 46.5 & 80 & 1,3,5-hexatriene & \\
\hline & & & & 82 & & \\
\hline 65 & 47.0 & 47.4 & 46.8 & 80 & - & \\
\hline 66 & 47.6 & 48.0 & 47.4 & - & - & \\
\hline 67 & 48.0 & 48.4 & 47.8 & - & - & \\
\hline \multirow[t]{2}{*}{68} & - & 48.6 & - & 82 & $\mathrm{C}_{6} \mathrm{H}_{10}$ & \\
\hline & & & & 86 & & \\
\hline 69 & - & 48.8 & - & 84 & 2-methyl-butene-1-one-3 & 21 \\
\hline 70 & 49.0 & 49.2 & - & - & - & \\
\hline 71 & 49.5 & 49.5 & 49.3 & - & - & \\
\hline 72 & 49.8 & - & - & - & - & \\
\hline 73 & 50.2 & 50.3 & 50.0 & 一 & - & \\
\hline 74 & 50.5 & 50.6 & 50.3 & 98 & 1-trans-2-dimethyl-cyclopentane & \\
\hline 75 & 50.6 & 50.8 & - & - & - & \\
\hline \multirow[t]{2}{*}{76} & 51.0 & 51.2 & 50.8 & 86 & & \\
\hline & & & & 96 & mixture & \\
\hline 77 & 51.4 & 51.6 & 51.2 & 96 & 2,5-dimethyliuran & 15,21 \\
\hline 78 & 51.7 & 51.8 & 51.5 & 96 & & \\
\hline & & & & 98 & mixture & \\
\hline & & & & 100 & & \\
\hline 79 & 52.0 & 52.0 & 51.8 & 98 & 2-methyl-2-hexene & \\
\hline 80 & 52.2 & 52.4 & 52.0 & 96 & & \\
\hline & & & & 98 & mixture & \\
\hline 81 & 52.6 & 52.8 & 52.4 & 94 & - & 21 \\
\hline & & & & 98 & & \\
\hline
\end{tabular}




\begin{tabular}{|c|c|c|c|c|c|c|}
\hline \multirow[b]{2}{*}{$\begin{array}{l}\text { Peak } \\
\text { no. }\end{array}$} & \multicolumn{3}{|c|}{$\begin{array}{l}\text { Gas chromatographlc.results } \\
\text { Retention time (min.) }\end{array}$} & \multirow[b]{2}{*}{$\begin{array}{c}\text { Molecular } \\
\text { welght }\end{array}$} & \multicolumn{2}{|l|}{ Mass spectrometric results } \\
\hline & HTL & HTB & Control & & Assignment & Ref.d \\
\hline 82 & 52.9 & 53.0 & 52.8 & - & 一 & \\
\hline 83 & 53.1 & 53.2 & 52.8 & $\begin{array}{l}92 \\
98\end{array}$ & $\begin{array}{l}\text { 1,5-heptadiene-3-yne } \\
\mathrm{C}_{7} \mathrm{H}_{14}\end{array}$ & \\
\hline 84 & 53.5 & 53.4 & - & - & - & \\
\hline 85 & 53.7 & 53.4 & 53.4 & 81 & 1-methylpyrrole & 21 \\
\hline 86 & 一 & 一 & - & 一 & - & \\
\hline 87 & 54.3 & 54.3 & 54.0 & 92 & - & \\
\hline 88 & - & 54.6 & 54.2 & - & - & \\
\hline 89 & 55.0 & 54.9 & 54.6 & 一 & 一 & \\
\hline 90 & 55.2 & 55.2 & 54.9 & 一 & - & \\
\hline 91 & 55.4 & 55.4 & 55.0 & 92 & 1,3,5-cycloheptatriene & \\
\hline & & & & 94 & & \\
\hline 92 & 55.7 & 55.6 & 55.4 & - & - & \\
\hline 93 & 56.8 & 56.3 & 56.5 & 92 & toluene & 15,21 \\
\hline 94 & - & 56.0 & 56.6 & 94 & 一 & \\
\hline 95 & 57.3 & 57.2 & - & - & - & \\
\hline 96 & 57.7 & 57.4 & 一 & 98 & methylthiophene & \\
\hline 97 & 57.8 & 57.6 & 57.4 & 96 & 1-methylcyclohexene & \\
\hline 98 & 58.0 & 58.0 & 57.6 & 112 & 2,5-dimethyl-2-hexene & \\
\hline 99 & 58.4 & 58.4 & - & 114 & 2,5-dimethylhexane & \\
\hline 100 & 59.0 & 58.8 & 58.0 & - & 一 & \\
\hline 101 & 59.4 & 59.4 & 59.2 & 112 & - & \\
\hline 102 & 60.0 & 60.0 & 一 & 92 & - & \\
\hline & & & & 112 & & \\
\hline 103 & 60.2 & 60.2 & - & - & - & \\
\hline 104 & 60.3 & 60.4 & - & - & - & \\
\hline 105 & 60.6 & 60.6 & 60.2 & 110 & & \\
\hline & & & & 112 & mixture & \\
\hline 106 & 61.6 & 61.7 & 61.4 & 112 & & \\
\hline & & & & 114 & $\mathrm{C}_{8} \mathrm{H}_{18}$ & \\
\hline 107 & 62.0 & 62.0 & 61.8 & - & - & \\
\hline 108 & 62.8 & 62.8 & - & - & - & \\
\hline 109 & 63.1 & 63.2 & 62.8 & 110 & 2,5-dimethyl-2,4-hexadiene & \\
\hline 110 & 64.0 & 64.0 & - & 120 & - & \\
\hline$\$ 11$ & 65.0 & 65.0 & 一 & 120 & & \\
\hline & & & & 122 & mixture & \\
\hline 112 & 65.8 & 65.8 & 65.4 & 106 & ethylbenzene & 15,21 \\
\hline 113 & 66.3 & 66.4 & 66.0 & - & - & \\
\hline 114 & 66.6 & 66.8 & 66.4 & 106 & m-, p-xylene & 15,21 \\
\hline 115 & 68.3 & 68.4 & 68.0 & 104 & styrene & 15,21 \\
\hline 116 & 68.6 & 68.8 & 68.3 & 106 & o-xylene & 15,21 \\
\hline 117 & 69.0 & 69.0 & 68.6 & 124 & 7-methyl-2,4-octadiene & \\
\hline 118 & 69.3 & 69.4 & 69.0 & - & - & \\
\hline 119 & 69.6 & 69.6 & 69.2 & 122 & & 22 \\
\hline 120 & 70.0 & 70.2 & 69.7 & - & - & \\
\hline 121 & 70.4 & 70.4 & 70.0 & 一 & 一 & \\
\hline 122 & 71.3 & 71.4 & 71.0 & - & 一 & \\
\hline 123 & 74.6 & 74.6 & 74.1 & - & - & \\
\hline 124 & 75.0 & 75.0 & - & - & 一 & \\
\hline 125 & 75.2 & 75.4 & - & 120 & methyl-ethylbenzene & 21 \\
\hline 126 & 75.4 & 75.6 & 75.0 & 136 & sylvestrene & 21 \\
\hline 127 & 77.4 & 77.6 & - & - & 一 & \\
\hline 128 & 78.0 & 78.2 & - & - & - & \\
\hline 129 & 78.5 & 78.8 & 78.1 & 138 & dihydroterpene & \\
\hline 130 & 79.0 & 79.2 & 78.6 & 138 & dihydroterpene & \\
\hline 131 & 79.7 & 80.0 & 79.2 & 138 & dihydroterpene & \\
\hline 132 & 80.6 & 80.9 & 80.1 & 134 & tert. butylbenzene & \\
\hline 133 & 81.2 & 81.5 & 80.8 & 138 & m-menth-3(8-)-ene & \\
\hline 134 & 81.8 & 82.0 & 81.2 & 136 & limonene & 15 \\
\hline
\end{tabular}

a: Substance, only found in HTL. b: Substance, only found in HTB. $\quad$ c: Substance, only found in control. d: The references given refer to publications dealing with compounds earlier found in tobacco smoke. 


\section{REFERENCES}

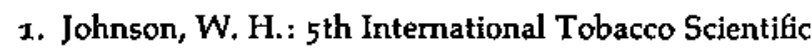
Congress, Hamburg, 1970 .

2. Weeks, W. W., and Johnson, W. H.: 5 th International Tobacco Scientific Congress, Hamburg 1970.

3. Johnson, W. H., and Gwynn, G. R.: Tobacco Science 16 (1970) 1 .

4. Humphries, E. G., and Johnson, W. H.: Tobacco Science 8 (1964) 96.

5. Bradford, J. A., Harlan, W. R., Hammer, H. R.: Ind. Eng. Chem. 28 (1936) 836.

6. Bulletin d'Information du CORESTA 1969-1.

7. Bulletin d'Information du CORESTA 1969-2.

8. Williamson, J.: Private communication.

9. Carlson, C.: Unpublished results.

10. Dalhamn, T.: Arch. Environmental Health, in press.

11. Enzell, C. R., Bergstedt, E., Dalhamn, T., and Johnson, W. H.: Beitr. Tabakforsch. 6 (x971) $4 x$.

12. Bartle, K. D., Bergstedt, L., Novotn'y, M., and Widmark, G.: J. Chromatography 45 (x969) 256.

13. Novotn'y, M.: Chromatographia 2 (1969) 350.

14. Bergstedt, L., and Widmark, G.: Chromatographia 2 (1969) 529.

15. Völlmin, J. A., Omura, I., Seibl, J., Grob, K., and Simon, W., Helv. Chim. Acta 49 (1965) 1768.

16. Grob, K.: Beitr. Tabakforsch. 3 (1966) 403.
17. Cornu, A., and Massot, R.: Compilation of mass spectral data, Heyden \& Son, London 1966 , and First Supplement, London 1967.

18. Stenhagen, E., Abrahamsson, S., and McLafferty, S. W.: Atlas of mass spectral data, John Wiley and Sons, New York 1969.

19. Sydow, E. von, Anjou, K., and Karlsson, G.: Swedish Institute for Food Preservation Research, Report No. 279, Göteborg 1970.

2o. Enzell, C. R., Appleton, A., and Wahlberg, I.: in Waller, G. R. (Ed.), Biochemical applications of mass spectrometry, John Wiley and Sons, in press, and references quoted here.

21. Elmenhorst, H., and Schultz, Ch.: Beitr. Tabakforsch. 4 (1968) go.

22. Grob, K., and Völlmin, J. A.: Beitr. Tabakforsch. 5 (1969) 52.

23. Grob, K.: Private communication.

\section{Acknowledgement}

We are indebted to. Mr. L. Hjern and his staff of the Swedish Tobacco Co., Stodkholm, for the determination of TMP, dry condensate, nicotine, and phenol.

The authors' address:

Swedish Tobacco Company,

Research Department,

P.O. Box 17007,

S-10462 Stodkholm 17, Sweden.

\section{Erratum}

Page 99, left column:

In the $7^{\text {th }}$ and $10^{\text {th }}$ line the word "reduction" should be replaced by "increase". 